\title{
Effect of BAP (6-Benzyl Aminopurine) on In Vitro Shoot Growth of Curcumas
}

\author{
Rustikawati*, Catur Herison, Entang Inoriah and Vera Dwisari \\ Department of Crop Production, Faculty of Agriculture, University of Bengkulu \\ *Corresponding author: rustikawati@unib.ac.id
}

\begin{abstract}
Curcuma $\mathrm{sp}$ has been widely investigated for its anti-cancer properties. Conventionally, vegetative propagation needs a long time to produce a large number of planting materials, so that it is necessary to find an alternative approach through in vitro propagation. The effect of BAP on the in vitro shoot formation of 'temu putih' and 'temu putih' has been investigated in this study. The experiment was a $4 \times 2$ factorial with 5 replications arranged in a completely randomized design. The first factor was the concentration of BAP i.e. 0, 1.5, 3, and $4.5 \mathrm{ppm}$. The second factor was the curcuma species consisting of 'temu putih' (Curcuma zedoaria Roch.) and 'temu mangga' (Curcuma mangga Val.). Each experimental unit consisted of 2 in vitro bottles, each of which planted with 1 explant bud. Analysis of variance was conducted on percentage of live explants, shoot height, number of roots, root length, wet weight, percentage of explants that sprouted, percentage of rooted explants and shoot color. Mean comparison was performed by the Least Significant Difference (LSD). The results showed that there was no interaction between BAP concentration and genotype on any variable observed. The shoot growth of temu putih' was significantly higher than 'temu mangga' in vitro. The best concentration of BAP for the growth of 'temu putih' and 'temu mangga' shoots was $1.5 \mathrm{ppm}$.
\end{abstract}

Keywords: cytokinine, 'temu putih', 'temu mangga', in vitro

Citation to this paper should be made as follows:

Rustikawati, C. Herison, E. Inoriah and V. Dwisari. 2021. Effect of BAP (6-Benzyl Aminopurine) on In Vitro Shoot Growth of Curcumas. Agritropica: Journal of Agricultural Science. 4 (1): 82-92. DOI: https://doi.org/10.31186/Jagritropica.4.1.82-92.

\section{INTRODUCTION}

Zingiberaceae is often referred to as curcumas herbal medicine in Indonesia, and this type of plant is also found in many other tropical areas, especially in Southeast Asia. The Curcuma genus is widely used as a raw material for spices and herbal medicines. This is because the plant contains curcumin which is useful as an anti-tumor and anti-oxidant (Putri, 2014); Murwanti et al. (2004); Abas et al. (2005). The anti-cancer mechanism of 'temu putih' extract is to induce apoptosis of cancer cells without damaging other cells around them and inhibiting the proliferation of cancer cells (Lakshmi et al. 2011). Several researchers have tested the health efficacy of the curcuma rhizome. 'Temu putih' rhizome is useful as an essential oil which contains flavonoids and sesquiterpenes. Both of these compounds have a function as hepatoprotectors, antioxidants and antiinflammatory agents (Widono and Parfiani, 2002). Furthermore, Sembiring and Suarnella (2012) revealed that the essential oil of 'temu putih' rhizome with a concentration of $54.5 \mathrm{ppm}$ eradicates larvae of mosquito (Aedes aegypti). Meanwhile, the rhizome of 'temu mangga' is proven to be able to prevent damage of pancreatic $\beta$ cells in white mice (Hendrikos et al., 2014).

Recently, public awareness on the negative effects of chemical drugs 
increases. The use of herbal medicine has become an alternative remedy and many of them were prepared from 'temu putih' and 'temu mangga'. However, the problem is producing offspring in rhizome propagated plants takes a long time. The conventionally propagated 'temu putih' takes at least 9 months with a total production of 16-17 times as much as the initial rhizome weight (Syukur, 2003).

One manner to do vegetative propagation is in vitro culture. In vitro culture is a propagation technique that isolates certain plant parts and then stimulates them to form a whole new plant by modification the growing medium and environment suitable for the plant (Sharma et al., 2015). In vitro culture technique is able to produce large numbers of planting materials in a relatively short time, uniform, pathogen-free, and season independen (Mastuti, 2017).

In in vitro culture, the growth and development of the explants is strongly affected by the type of their basic media and growth regulators. Murashige and Skoog (MS) media is a basic medium generally used for propagating a variety of plant species. This basic medium is rich in minerals which stimulate organogenesis. The MS medium provided good growth in the propagation of various rhizome producing plants, such as 'temu mangga' (Raihana et al., 2011); 'temu lawak' (Waryastuti et al., 2017); 'temu hitam' (Singh et al., 2015); turmeric (Antoniazzi et al., 2016).

To increase explant multiplication, generally, growth regulators in the form of both auxin and cytokinin groups are supplemented in the growing media. These growth regulators stimulate the process of growth and development of plant tissue. In 'temu mangga' culture, supplementation of $5 \mathrm{mg} / \mathrm{L} \mathrm{BA}$ and 0.1 $\mathrm{mg} / \mathrm{L}$ NAA was the most suitable for the plantlets. Meanwhile, the addition of 1 $\mathrm{mg} / \mathrm{L}$ 2,4-D in MS medium induced callus formation in ginger shoot explants (Jala, 2013).

Benzyl amino purine is a type of cytokinin the most often used in shoot propagation because it is stable, resistant to degradation and readily available (Zulkarnain, 2009). In vitro culture of 'temu putih' in MS medium enriched with up to 4.5 ppm BAP and 4.5 ppm sucrose increased shooot growth up to six times and the number of shoots three times as much as control (Yulizar et al., 2014). 'Temu mangga' sub-cultured on MS medium containing BA at a concentration of up to 5 $\mathrm{mg} / \mathrm{L}$ increased explants to form buds (Hutami \& Purnamaningsih, 2003). However, there is little information on 'temu putih' and 'temu mangga'. The objective of this study was to evaluate the shoot growth response of 'temu putih' and 'temu mangga' to the supplementation of BAP on the MS basic medium in vitro.

\section{MATERIALS AND METHOD}

\section{Establishment of aseptic equipment and explants}

The tools used such as culture jars, petri dishes, tweezers, and scalpel blades were washed thoroughly by detergent and running water. The glassware was sterilized using hypochlorite and then autoclaved at a temperature of $121^{\circ} \mathrm{C}$ and a pressure of 15 psi for 30 minutes. Metal tools and petri dishes were paper-wrapped and sterilized in a medical sterilizer at $280^{\circ} \mathrm{C}$ for 10 minutes.

The basic medium used was MS medium which was supplemented with vitamins. Growth regulator of BAP was added according to the treatments. The media was also enriched with $5 \%$ sugar and 0.05 ppm NAA to stimulate shoot growth, added as much as $7 \%$ agar as the compaction agent, and adjusted at the $\mathrm{pH}$ 
5.7. The media was put into vessels as much as $20 \mathrm{~mL}$ each and capped with transparent high temperature resistant plastic and tightly tied with rubber band. All media were then autoclaved at pressure 15 psi and temperature $121^{\circ} \mathrm{C}$ for $15 \mathrm{~min}$.

Explants in the form of buds from healthy rhizomes were cut into $1 \mathrm{~cm}$ long in size washed with running water, soaked in detergent 30 minutes, and then rinsed with distilled water 3 times. The cleaned explants were soaked in a bactericide and fungicide solution of $2 \mathrm{~g} / \mathrm{L}$ for 30 minutes and rinsed with distilled water 3 times. Further sterilization was continued in the laminar air flow cabinet (LAC). The explants were immersed in $20 \%$ hypochlorite solution for 7 minutes, 10\% hypochlorite for 10 minutes, and 5\% hypochlorite for 15 minutes before being washed with sterile water three times, and then soaked in a concentrated bethadine solution for 3 minutes. Sterile explants were implanted into the media in the sterile environment and the vessels were recapped tightly and wrapped with plastic wrap.

After inoculation, the cultures were placed in tissue culture room at $25^{\circ} \mathrm{C}$ with 1000 lux light intensity (Shukla et al., 2005). The culture room was kept free bacteria and fungi contaminant by application of $10 \%$ formalin once a week.

\section{Experimental design statistical analysis}

Explants of 'temu putih' and 'temu mangga' were previously sterilized in the standard procedure of tissue culture (Yulizar et al., 2014) and grown in the basic media of MS for two weeks to screen the healthy and pathogen-free plant materials in the Tissue Culture Laboratory of the Department of Crop Production, Faculty of Agriculture, The University of Bengkulu on November in the year of 2018. The non- contaminated explants, then, were transferred into the MS media supplemented with benzyl adenine at the rate of $0,1.5,3$, or $4.5 \mathrm{ppm}$, and kept in culture room. The experiment was a completely randomized design with 5 replications, arranged in a $2 \times 4$ Factorial. The first factor was curcuma species, i.e. 'temu putih' and 'temu mangga', and the second factor was the concentration of BAP. The experimental unit was two tissue culture vessels, each of which was planted with single bud eye explant.

Data were collected at one to seven weeks after planting on percentage of live explants, shoot height, number of roots, root length, fresh weight of plantlets, percentage of sprouted explants, percentage of rooted explants and shoot color.

The data was analyzed with Analysis of variance (ANOVA) and the mean comparisons were conducted with the least significant difference (LSD) at $\mathrm{P}<0.05$.

\section{RESULTS AND DISCUSSION}

\section{Establishment of in vitro culture}

Explants of 'temu putih' showed different responses to in vitro culture from 'temu mangga' since they were planted in the culture media. 'Temu putih' exhibited explants swelling earlier than 'temu mangga'. By the second week after transplanting, the yellowish white explants of 'temu putih' have already swollen at the incision scar. At the third week the explants changed into a green color, which was the growing point of the new shoots. The perfect leaves of 'temu putih' were formed at four weeks, while that of 'temu mangga' at six weeks after transplanting. The plantlets which had been completed with roots and shoots developed to form new leaves at the following week. Figure 1 was the visualization of the development 
of 'temu putih' explants and 'temu manga' until the sixth week after transplanting.

In this study, each explant formed single shoot. This was presumably because the size of the initial explants was too small and the composition of the media required for shoot multiplication was not appropriate. Zulkarnain (2009) stated that the smaller the explant size, the smaller the regeneration ability, but the lesser the chance of contamination.
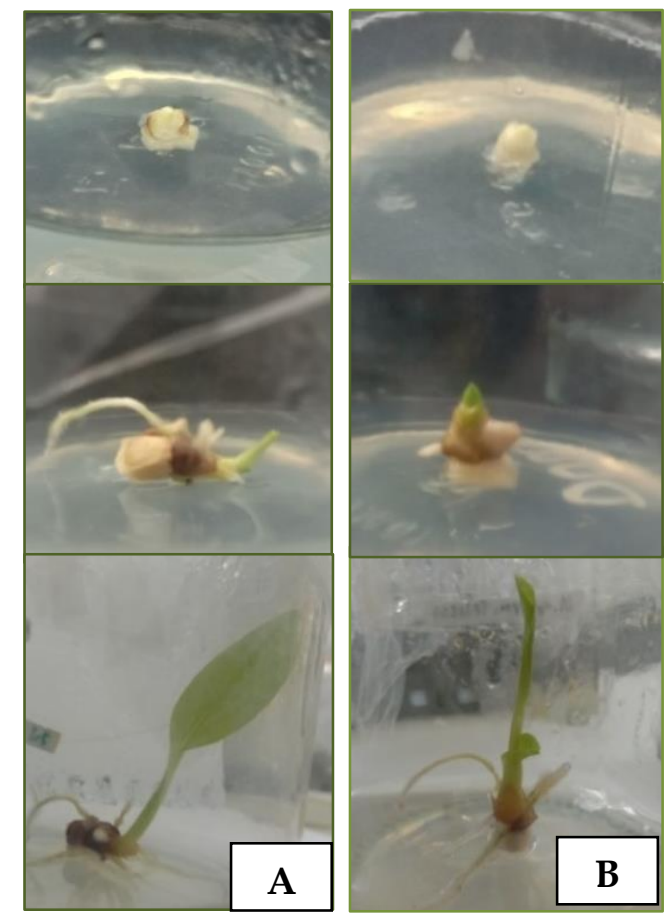

Figure 1. Shoot development of 'temu

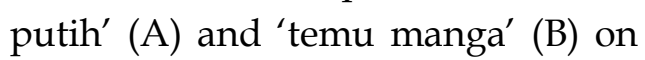
MS media with the addition of 1.5 ppm BAP

The development of explants between replications showed a high variation. Therefore, the results of the analysis of variance on the growth of the curcuma explants at various concentrations of BAP in vitro exhibited a high coefficient of variation (CV). This coefficient is a description of the magnitude of the experiment error which interfere the reliability of the conclusions. The reliable value of the $\mathrm{CV}$ according to Herdianto (2013) was less than 30\%.
Therefore, to fulfill the prerequisite of ANOVA, transformation was carried out by $\sqrt{ }(X+1)$ on the data collected.

The results of the $F$ test on all variables indicated that there was no effect of interaction between the type of curcuma and the rate of BAP. Both curcumas revealed the same response pattern to the increasing rate of BAP. They possibly possessed similar amount of food and hormones. In early shoot development, the role of plant endogenous hormones was predominant. Each shoot possessed a reserve of food and hormones to stimulate growth so that it could grow without additional of external growth regulators. The food reserved of the explants triggered differences in shoot growth and development (Cahyati et al., 2016).

Type of curcuma significantly affected plant height, number of roots, fresh weight of plantlets and not significant on root length and percentage of live explants. Meanwhile, the BAP treatment showed a significant difference in all the variables tested (Table 1). The percentage of live explants was not affected by the type of curcuma or BAP, and there was no interaction between the two factors. The total live explants were more than $80 \%$ of the explants planted. This data indicated the successful of explant sterilization. However, only $60 \%$ of the total planted explants were able to produce shoots, while $20 \%$ showed no growth response. The explants which experienced growth stagnation until the sixth week were thought to be physiologically immature because the explants were probably cut too small in size. According to Shukla et al., (2007) the size of explants that are ready to be regenerated in vitro is $2 \mathrm{~cm}-3 \mathrm{~cm}$. At this size, the availability of food reserves and growth hormone was sufficient so that the explants are able to multiply into many shoots. 
Table 1. Analysis of variance of 'temu putih' and 'temu mangga' explants at several concentrations of BAP at seven weeks after transplanting.

\begin{tabular}{lcccr}
\hline \multirow{2}{*}{ Variable } & \multicolumn{3}{c}{ Value of $\mathbf{F}_{\text {calculated }}$} & \multirow{2}{*}{ CV (\%) } \\
\cline { 2 - 4 } & Interaction & $\begin{array}{c}\text { Type of } \\
\text { curcuma }\end{array}$ & BAP & (c) \\
\hline Percentage of live explants & $1.4^{\mathrm{ns}}$ & $0.12^{\mathrm{ns}}$ & $2.4^{\mathrm{ns}}$ & 26.6 \\
Plant height & $2.4^{\mathrm{ns}}$ & $6.05^{*}$ & $4.4^{*}$ & 15.7 \\
Root length $^{\mathrm{t}}$ & $0.6^{\mathrm{ns}}$ & $2.62^{\mathrm{ns}}$ & $2.9^{*}$ & 23.2 \\
Number of root $^{\mathrm{t}}$ & $0.8^{\mathrm{ns}}$ & $5.14^{*}$ & $2.9^{*}$ & 29.7 \\
Fresh-weight of plantlet $^{\mathrm{t}}$ & $1.9^{\mathrm{ns}}$ & $6.05^{*}$ & $3.1^{*}$ & 7.0 \\
\hline
\end{tabular}

Note: $\mathrm{t}$ : data is transformed by $\sqrt{ }(X+1)$, ns: not significance, ${ }^{*}=$ significance at $\alpha=5 \%$

Shoot Growth of Curcuma sp in vitro

Shoot growth of 'temu putih' in vitro was slightly different from that of 'temu mangga', in term of plant height, number of root and fresh-weight of plantlet. The difference was observed at seven weeks after transplanting. The shoot height of the 'temu putih' was significantly higher than that of 'temu mangga'. In addition, at the same age, 'temu putih' also possessed higher number of roots and plantlet fresh weight than 'temu mangga' (Table 2).

The difference in shoot growth in vitro of two curcuma species may be attributable to the difference of genetically controlled of endogenous hormones. Das et al. (2010) was also found that different species of curcuma exhibited different responsiveness to in vitro environment for shoot multiplication. Species determines genetic relationship in curcumas (Saha et al., 2016)

\section{The Effect of BAP on the Shoots Growth of Curcumas}

The addition of exogenous growth regulators increased shoot growth of
Curcuma sp. The highest increased in shoot growth was obtained in 1.5 ppm BAP. However, BAP concentrations of more than 1.5 ppm increased shoot growth in lesser intensity. There was a significant difference in all growth variables of Curcuma between control and the addition of 1.5 ppm BAP at seven weeks after transplanting. Plant height increased more than 5 times compared to controls (Table 3). In this study, each explant produced only one shoot and some explants showed symptoms of stagnation which was not any further development. Less number of shoot produced per explant maybe related to small size of explant. Some other studies used larger shoot size to increase number of shoots Shukla et al., (2007). Bharalee et al. (2005) was successful in multiplication of Curcuma zedoaria up to 4 shoots per explant with the rhizome bud explant of about $2 \mathrm{~cm}$ in size. Smaller explant size has the advantage of lower potential for contamination, but it has the disadvantage of less growth response to in vitro environment.

Table 2. The growth of 'temu putih' and 'temu mangga' in vitro

\begin{tabular}{lccc}
\hline Curcuma species & Shoot height $(\mathrm{cm})$ & Number of roots & Shoot fresh weight $(\mathrm{g})$ \\
\hline 'Temu Putih' & $0.72 \mathrm{a}$ & $1.07 \mathrm{a}$ & $0.22 \mathrm{a}$ \\
'Temu Mangga' & $0.28 \mathrm{~b}$ & $0.25 \mathrm{~b}$ & $0.09 \mathrm{~b}$ \\
\hline Note: Numbers followed by the same letter in the same column are not significantly different at \\
P $<0.05$ according to LSD.
\end{tabular}


Tabes 3. The effect of BAP concentration on the growth of 'temu putih' and 'temu mangga' at 7 MST

\begin{tabular}{ccccc}
\hline $\begin{array}{c}\text { Concentration of } \\
\text { BAP }\end{array}$ & $\begin{array}{c}\text { Shoot height } \\
(\mathrm{cm})\end{array}$ & $\begin{array}{c}\text { Number of } \\
\text { root }\end{array}$ & $\begin{array}{c}\text { Root length } \\
(\mathrm{cm})\end{array}$ & $\begin{array}{c}\text { Plantlet fresh weight } \\
(\mathrm{g})\end{array}$ \\
\hline $0 \mathrm{ppm}$ & $0.18 \mathrm{~b}$ & $0.00 \mathrm{~b}$ & $0.00 \mathrm{~b}$ & $0.06 \mathrm{~b}$ \\
$1.5 \mathrm{ppm}$ & $1.03 \mathrm{a}$ & $1.40 \mathrm{a}$ & $0.89 \mathrm{a}$ & $0.30 \mathrm{a}$ \\
$3.0 \mathrm{ppm}$ & $0.44 \mathrm{~b}$ & $0.80 \mathrm{ab}$ & $0.56 \mathrm{ab}$ & $0.13 \mathrm{~b}$ \\
$4.5 \mathrm{ppm}$ & $0.37 \mathrm{~b}$ & $0.45 \mathrm{ab}$ & $0.14 \mathrm{~b}$ & $0.13 \mathrm{~b}$ \\
\hline
\end{tabular}

Note: Numbers followed by the same letter in the same column are not significantly difference according to LSD at $\mathrm{P}<0.05$.

Shoot growth in vitro required a suitable auxin and cytokinin balance. In this study, MS basic media with 0.05 ppm NAA, combined with 1.5 ppm BAP, was most suitable for the growth of 'temu putih' and 'temu mangga'. BAP cytokinin plays a role in cell division, however, when it was combined with a little amount of auxin, it can also encourage cell elongation. In this study, this effect was expressed in increasing shoot height. A concentration of 1.5 ppm BAP had the best effect on shoot height. Klerk (2002) stated that high concentrations of cytokinin can also inhibit cell elongation so that the explants were difficult to elongate. The number of formed shoots increased but the growth of each shoot decreased. Ali et al. (2008) also revealed that cytokinin play a role in the process of cell division and plant regeneration by stimulating callus to differentiate to form shoots, but exceeding the optimum limit will be toxic to plant tissue.

The role of BAP on the formation and lengthening of Curcuma sp roots was significant. Without BAP, neither 'temu putih' nor 'temu mangga' was able to form roots even though the shoots have developed (Table 3). The supplementation of 1.5 ppm BAP also resulted in the highest number of roots in either 'temu putih' or 'temu mangga'. However, at higher concentrations of up to 4.5 ppm BAP, the enhancement of the number of roots was slightly lowered. Similar response was observed on the root length. At 4.5 ppm $\mathrm{BAP}$, there was a significant decrease in the increase of root length. Root growth was affected by endogenous auxins. The addition of BAP in high concentrations might inhibit root growth. Increasing the concentration of BAP was found to decrease the number and length of roots of white turmeric (Kaempfreria rotunda L.) plants linearly (Arniputri \& Purnomo, 2003). According to Siregar et al., (2013), BAP affects root growth through the shoot growth. Shoot development does not need a lot of exogenous auxin because it has already possessed endogenous auxin. The excessive exogenous auxins application actually inhibits root growth. Pamungkas (2015) showed that, in banana explants, the longest roots were observed at a BAP concentration of $3 \mathrm{ppm}$ and decreased at higher concentrations up to $9 \mathrm{ppm}$. Cytokinins are able to stimulate root growth under an optimum rate but inhibit it at higher BAP concentrations.

Increasing plant height and number and length of roots have implications for increasing plantlet fresh weight. The treatment of $1.5 \mathrm{ppm}$ BAP exhibited the highest fresh weight of plantlets and the enhancement of shoot fresh weight lessen significantly at higher BAP concentration. Fresh weight of plantlets is the most important variable indicating the accumulation of plant assimilates. The larger the plantlets, the higher the fresh weight. Sintha (2017) also 
revealed that the fresh weight of banana explants was influenced by the developing explants. The greater the increase in explant growth, the greater the fresh weight.

\section{Plant Growth Pattern}

The addition of various concentrations of BAP on MS +0.05 ppm NAA basic media resulted in different trends in the growth pattern of 'temu putih'. Observations until the seventh week after planting showed that a concentration of 1.5 ppm BAP induced a greater increase in plant height. The exponential rate of increase began at week 5 after transplanting (Figure 2). The trend of increasing plant height was different from the addition of BAP at a higher concentration which tends to level off. Figure 2 also confirmed the important of BAP in shoot growth of curcumas in vitro. Without BAP, the growth of curcuma in vitro was very limited.

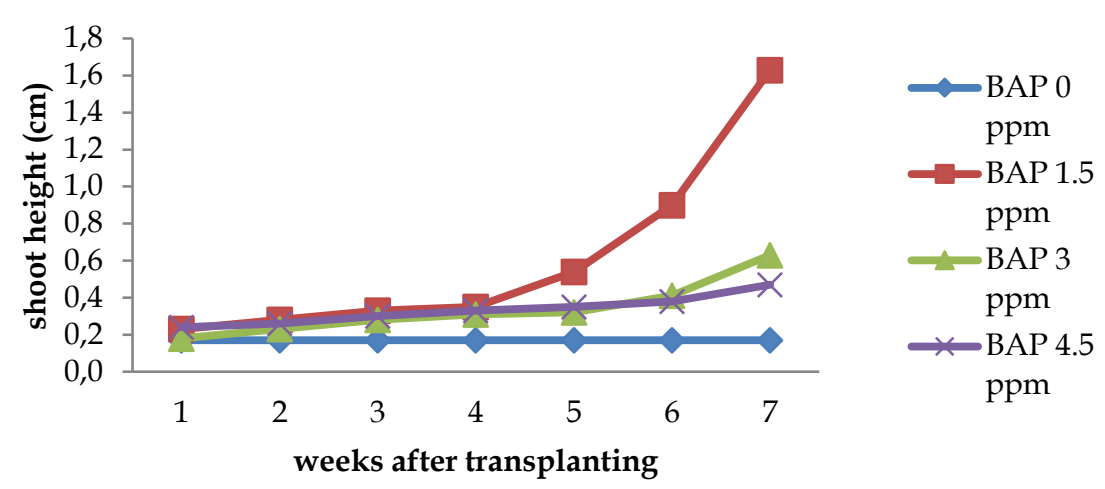

Figure 2. Graph of shoot height growth of 'temu putih' plants on several BAP concentrations

The growth pattern of 'temu manga' was also similar to that of 'temu putih'. A concentration of 1.5 BAP resulted in a rapid growth pattern at plant height (Figure 3). Although, the greatness of enhancement in 'temu mangga' was lower than that in 'temu putih'.

The supplementation of BAP type cytokinins was very effective in increasing the growth of shoots and roots of 'temu putih' and 'temu mangga'. In the control treatment, without the addition of BAP, explants did not form shoots and roots until the seventh week. The best BAP treatment for shoot formation was $1.5 \mathrm{ppm}$ with a percentage of shoot growth above $50 \%$ for both 'temu putih' and 'temu mangga' (Figure 4). Auxin and cytokinin balance in early plant growth greatly affects the growth rate of explants.

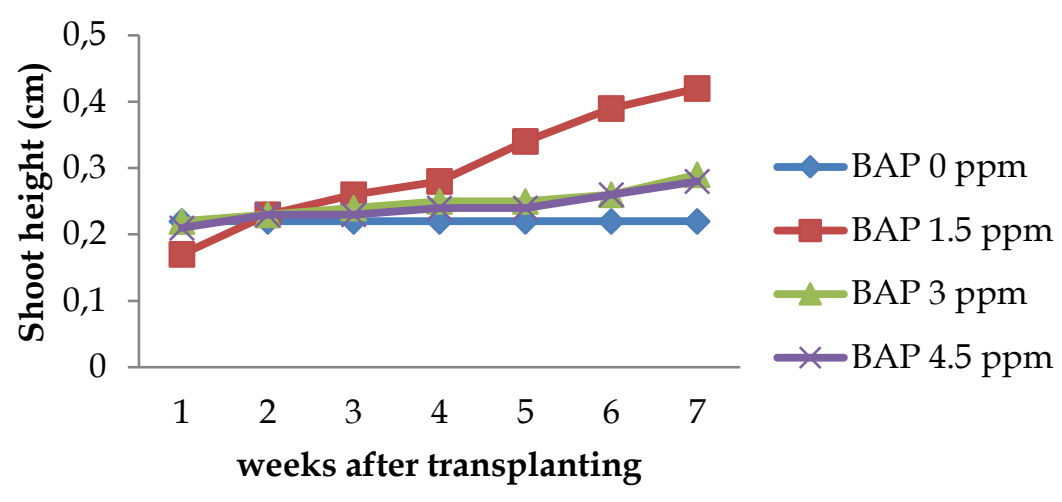

Figure 3. Graph of the height growth of mango root crops at several concentrations of BAP 
Concentrations of BAP above 1.5 ppm inhibited the formation of 'temu putih' shoots and 'temu mangga'. Similar results were obtained by Siregar et al., (2013) in Boesenbergia flava culture. According to Arniputri and Purnomo (2003), a high concentration of BAP will stimulate an increase in the number of shoots so that the effect of shoot lengthening is inhibited by the formation of new shoots. Based on all variables observed, it was noticeable that 'temu putih' has a better growth response on the supplementation of BAP than 'temu mangga'. Aulia (2020) also found the formation of in vitro shoots in 'temu putih' with the addition of 5 ppm BA, but none was obtained in 'temu mangga'
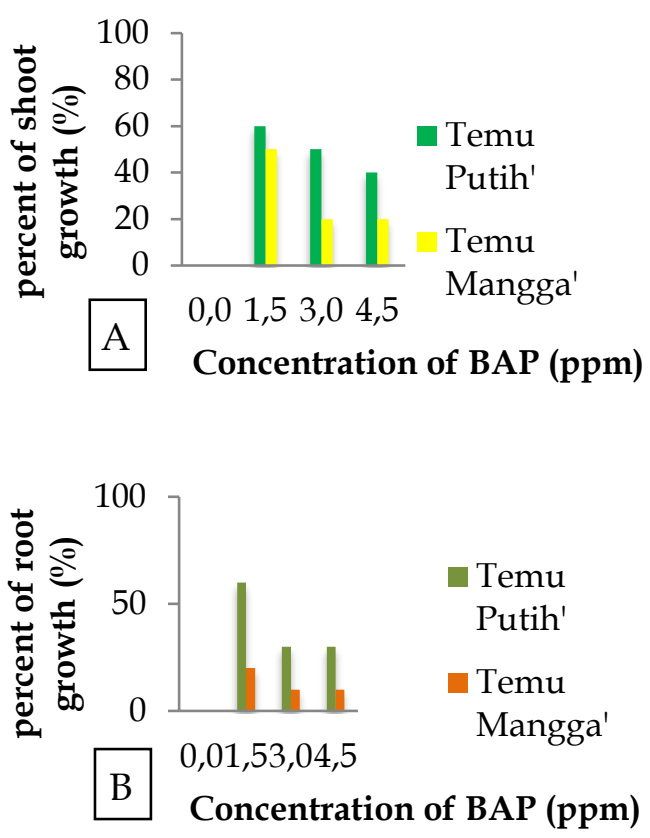

Figure 4. Percentage of shoots (A) and roots (B) in 'temu putih' and 'temu mangga' explants with the addition of BAP at the age of 7 weeks after transplanting.

This confirmed that the growth of explants was strongly affected by plant genetics which controls the ability of plants to use external growth regulators and plant endogenous hormones to stimulate growth (Cosic et al., 2015).

In in vitro propagation, the success of forming plantlets is often preceded by shoot formation. The formation of roots at the base of the shoots is sometimes become an obstacle for certain plants. In this research, the plantlets were formed perfectly with shoots and roots. The number of rooted explants increased with the addition of BAP of $1.5 \mathrm{ppm}$. The addition of NAA to the basic media was thought to trigger the formation of the roots of 'temu putih' and 'temu mangga'. According to Miryam et al., (2008), the addition of auxins without cytokinins to the media increased the number of roots compared to cytokinin without auxin. Likewise, Cosic et al., (2015) stated that the effectiveness of exogenous auxin application on root formation was influenced by the content of endogenous cytokinins and IAA.

\section{CONCLUSION}

Benzyl amino purine is able to increase the shoot growth of 'temu putih' and 'temu manga' in vitro. Benzyl amino purine of $1.5 \mathrm{ppm}$, when it was supplemented to the MS basic medium with 0.05 ppm NAA, is the optimum rate to stimulate in vitro shoot and root growth of curcumas. 'Temu putih' is more responsive to benzyl amino purine than 'temu mangga'.

\section{REFERENCE}

Abas, F., Lajis, N.H., Shaari, K., Israf, D.A., Stanslas, J., Yusuf, U.K., Raof. S.M. (2005). A labdane diterpene glucoside from the rhizomes of Curcuma mangga. J Nat Prod. 68(7),1090-1093. doi: 10.1021/np0500171.

Ali, A., Naz, S., Siddiqui, F.A. and Iqbal, J. (2008). Rapid clonal 
multiplication of sugarcane (Saccharum officinarum) through callogenesis and organogenesis. Pakistan Journal of Botany, 40(1),123.

Antoniazzi, D., de-Souza-Ferrari, M.P., Nascimento, A.B., Silveira, F.A., Pio, L.A.S., Pasqual, M. \& Magalhães H.M. (2016). Growth regulators, DNA content and anatomy in vitro-cultivated Curcuma longa seedlings. Afric. J. Biotech., 15(32), 1711-1725.

Arniputri, R.B. dan Purnomo, D. (2003). Pengaruh konsentrasi IAA dan BAP terhadap pertumbuhan dan perkembangan tanaman kunir putih (Kaempferia rotunda L.) Secara in vitro. Agrosains, 5(2),48-51.

Aulia, M.I., Rustikawati dan Inoriah. E. (2020). Respon temu putih dan temu mangga dengan pemberian BA dan 2,4-D secara in vitro. Gema Agro 25(2),92 102

Bharalee, R., Das, A.\& Kalita. M.C. (2005). In vitro clonal propagation of Curcuma caesia Roxb and Curcuma zedoaria Rosc from rhizome bud explants. J. Plant Biochem. Biotechnol. 14, 61-63 https://doi.org/10.1007/BF03263 228

Cahyati, S., Isda M.N., and Lestari. W. (2016). Induksi tunas dari ekplan kotiledon dan epikotil in-vitro jeruk siam (Citrus nobilis Lour.) asal kampar pada media MS. Jurnal Riau Biologia. 1(5), 31-38

Cosic, T., Motyka, V., Raspor, M., Savic, J., Cingel, A., Vinterhalter, B., Vinterhalter, D., Travnockova, A., Dobrev, P., Bohanec B., \& Nincovic. S. (2015). In vitro shoot organogenesis and comparative analysis of endogenous phytohormones in kohlrabi (Brassica oleracea var. Gongylodes): effects of genotype, explant type and applied cytokinins. PCTOC. 121,741-760

Das, A., Kesari, V., \& Rangan, L. (2010). Plant regeneration in Curcuma species and assessment of genetic stability of regenerated plants. Biologia Plantarum, 54(3), 423-429. doi:10.1007/s10535-0100077-0

Hendrikos, R., Marusin, N., and Tjong. D.H. (2014). Efek ekstrak etanol rimpang temu mangga (Curcuma mangga Val.) terhadap sel $\beta$ pankreas mencit putih yang diinduksi aloksan secara histologis. Jurnal Biologi Universitas Andalas. 3(4), 317-323

Herdiyanto, D. (2013). Rancangan Acak Lengkap. Jurusan Ilmu Tanah Universitas Padjajaran, Bandung

Hutami, S. dan Purnamaningsih, R. (2003). Perbanyakan klonal temu mangga (Curcuma mangga) melalui kultur in vitro. Balai Penelitian Bioteknologi dan Sumberdaya Genetik Pertanian. Bogor. 9(1), 39-44

Jala, A. (2013). The effect of the 2, 4dichlorophenoxy acetic acid, benzyl adenine and paclobutrazol, on vegetative tissue-derived somatic embryogenesis in turmeric (Curcuma var. Chattip). Int. Trans. J. Eng. Manag. Sci. Tech. 4(2), 105110.

Klerk, G.J. (2002). Plant hormones in tissue culture. Biochemical Plant Cell and Tissue Culture, Duchefa Biochemiev. 19-23.

Lakshmi, S., Padmaja, G., and Remani, P. (2011). Antitumour effects of 
isocurcumenol isolatedfrom Curcuma zedoaria rhizomes on human and murine cancer cells. International Journal of Medicinal Chemistry, 2011, 1-13. http://dx.doi.org/10.1155/2011/ 253962.

Mastuti, R. (2017). Dasar-dasar Kultur Jaringan Tumbuhan. Universitas Brawijaya Press, Malang

Miryam, A., Suliansyah, I. dan Djamaran, A. (2008). Multiplikasi jeruk kacang (Citrus nobilis L.) pada beberapa konsentrasi NAA dan BAP pada media WPM secara in vitro. Jerami, 1(2), 1-8.

Murwanti, R., Meiyanto, E., Nurrochmad, A., and Kristina, D.W. (2004). Efect ekstrak etanol rimpang temu putih (Curcuma zedoaria Roch.) terhadap pertumbuhan tumor paru fase post inisiasi pada mencit betina diinduksi Benzo[a]piren. Majalah Farmasi Indonesia, 15(1), 7-12.

Pamungkas, S.S.T. (2015). Pengaruh konsentrasi NAA dan BAP terhadap pertumbuhan tunas eksplan tanaman pisang cavendish (Musa paradisiaca 1.) melalui kultur in vitro. Gontor Agrotech Science Journal, 2(1), 3145.

Putri, M.S. (2014). White turmeric (Curcuma zedoaria) its chemical substance and the pharmacological benefit. Jurnal Majory, 3(7), 88-93

Raihana, R., Faridah, Q.Z., Julia, A.A., Abdelmageed, A.H.A., \& Kadir, M.A. (2011). In vitro culture of Curcuma mangga from rhizome bud. J. Med. Plants Res, 5(28), 6418-6422.

Saha, K. , Sinha, R., Basak, S. and Sinha, S. (2016) ISSR fingerprinting to ascertain the genetic relationship of curcuma sp. of tripura. American Journal of Plant Sciences, 7, 259-266. doi: 10.4236/ajps.2016.72025

Sembiring, W.S., dan Suarnella. D.T. (2012). Efektivitas minyak atsiri rimpang kunyit putih Curcuma zedoaria sebagai larvasida terhadap nyamuk Aedes aegypti. Jurnal Buski, 4(2), 80-86.

Sharma, G.K., Jagetiya, S. Dashora, R. (2015). General Techniques of Plant Tissue Culture. Lulu Press Inc. Raleigh, North Carolina

Shukla S K, Shukla, S., Koche , V., and Mishra, S. K. (2007). In vitro propagation of tikhur (Curcuma angustifolia Roxb.): A starch yielding plant. Indian J. Biotech., 6, 274-276

Singh, W.R., Singh, H.B., Devi, S.S., Singh, W.N., Singh, N.M., \& Devi, Y.P. (2015). Conservation of Curcuma caesia by in vitro techniques. Helix, 2, 708-713

Sintha, D. (2017). Pengaruh BAP dan kinetin terhadap pertumbuhan tunas pisang barangan (Musa paradisiaca L.) secara in vitro. Skripsi. Universitas Bengkulu, Bengkulu.

Siregar, L.H., Siregar, L.A.M., dan Putri. L.A.P. (2013). Pengaruh abenzil amino purin dan a-asam asetat naftalena terhadap pertumbuhan akar Boesenbergia flava secara in-vitro. Agroekoteknologi, 1(3), 511-522.

Syukur, C. (2003). Temu Putih Tanaman Obat Anti Kanker. Penerbit Swadaya, Jakarta

Waryastuti, D.E., Setyobudi, L. dan Wardiyati, T. (2017). Pengaruh tingkat konsentrasi 2,4-D dan BAP pada media MS terhadap 
induksi kalus embriogenik temulawak (Curcuma xanthorrhiza Roxb.). Jurnal Produksi Tanaman, 5(1), 140-149.

Widono, M.S., dan Parfiani, N. (2002). Curcuma zedoaria Roch. Kajian pustaka kandungan kimia dan aktifitas farmakologik. Artocarpus, 2(1), 1-10.
Yulizar, D.R., Noli, Z.A., and Idris, M. (2014). Induksi tunas kunyit putih (Curcuma zedoaria Roscoe) pada media MS dengan penambahan berbagai konsentrasi BAP dan sukrosa secara in vitro. Jurnal Biologi Universitas Andalas, 3(4): 310-316.

Zulkarnain, H., (2009). Kultur Jaringan Tanaman. Jakarta, Bumi Aksara 